\title{
Torrential rainfall in northeast of the Iberian Peninsula: synoptic patterns and WeMO influence
}

\author{
J. Martin-Vide ${ }^{1}$, A. Sanchez-Lorenzo ${ }^{1}$, J. A. Lopez-Bustins ${ }^{1}$, M. J. Cordobilla ${ }^{1,2}$, A. Garcia-Manuel ${ }^{1}$, and \\ J. M. Raso ${ }^{1}$ \\ ${ }^{1}$ Group of Climatology, University of Barcelona, Barcelona, Spain \\ ${ }^{2}$ Barcelona Regional, Barcelona, Spain
}

Received: 20 December 2007 - Revised: 7 April 2008 - Accepted: 24 April 2008 - Published: 4 June 2008

\begin{abstract}
This study presents a catalogue of synoptic patterns of torrential rainfall in northeast of the Iberian Peninsula (IP). These circulation patterns were obtained by applying a T-mode Principal Component Analysis (PCA) to a daily data grid (NCEP/NCAR reanalysis) at sea level pressure (SLP). The analysis made use of 304 days which recorded $>100 \mathrm{~mm}$ in one or more stations in provinces of Barcelona, Girona and Tarragona (coastland area of Catalonia) throughout the 1950-2005 period. The catalogue comprises 7 circulation patterns showing a great variety of atmospheric conditions and seasonal or monthly distribution. Likewise, we computed the mean index value of the Western Mediterranean Oscillation index (WeMOi) for the synoptic patterns obtained by averaging all days grouped in each pattern. The results showed a clear association between the negative values of this teleconnection index and torrential rainfall in northeast of the IP. We therefore put forward the WeMO as an essential tool for forecasting heavy rainfall in northeast of Spain.
\end{abstract}

\section{Introduction}

Torrential rainfall constitutes the climatic, and even natural, risk which causes the highest number of victims in Catalonia. The biggest natural catastrophe in Spain during the XX century involved flooding, caused by torrential rainfall, on 25-26 September 1962, in the Vallès Occidental region of Barcelona and the surrounding areas, with over 800 deaths and missing persons. The town of Rubí, with 5000 inhabitants, lost $10 \%$ of its population in the catastrophe. Numerous studies analyze the climatic characteristics, and often the synoptic ones, of intense rainfall episodes in the region (Martín Vide, 1994; Llasat, 1991; Martín Vide and Llasat, 2000, among others), or the meteorological causes of some of these episodes (Tomás Quevedo, 1963; Wheeler and Martín Vide, 1988; Llasat and Rodríguez, 1992; Ramis et al., 1994, 1997, among others).

The main climatic and meteorological characteristics of torrential rainfall in Catalonia can be summarized as follows: 1) abundance of cases; 2) relative seasonality; 3) short duration or low level of persistence; 4) preferential spatial distribution on the litoral-prelitoral and in the Pyrenees; 5)

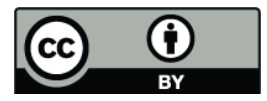

Correspondence to: J. Martin-Vide (jmartinvide@ub.edu) common drought-torrential rainfall binomial; 6) high contribution to annual totals; 7) variety of synoptic situations; and 8) difficulty to forecast (Martín Vide and Llasat, 2000; Martín Vide, 2006). The aforementioned variety of synoptic situations concurring in the origin of torrential rainfall in northeast of the Iberian Peninsula (IP) is somehow associated with its relationship with the Mediterranean climate, with the proximity to warm waters from the Mediterranean sea and with the orographic complexity of the territory. To date there has been no commonly used classification of the synoptic patterns associated with heavy rainfall in Mediterranean Spain, although different authors have identified potentially dangerous configurations that can give rise thereto, such as Levant advections with cold air at high tropospheric levels, upper-level depressions to the West or southwest of the region, the passing of a cold front from the West with a trough at $500 \mathrm{hPa}$, etc.

In the last two decades, the classification of atmospheric circulation patterns, specifically synoptic ones, has been promoted by the use of objective and semi-objective methods, based upon automatically calculated algorithms and multivariate procedures. This enables objective classifications to be established, which have substituted the traditional subjective or manual ones. The advantages of single-valued identification of the types obtained and of the transfer and replication of the classifications obtained are unarguable. However, 


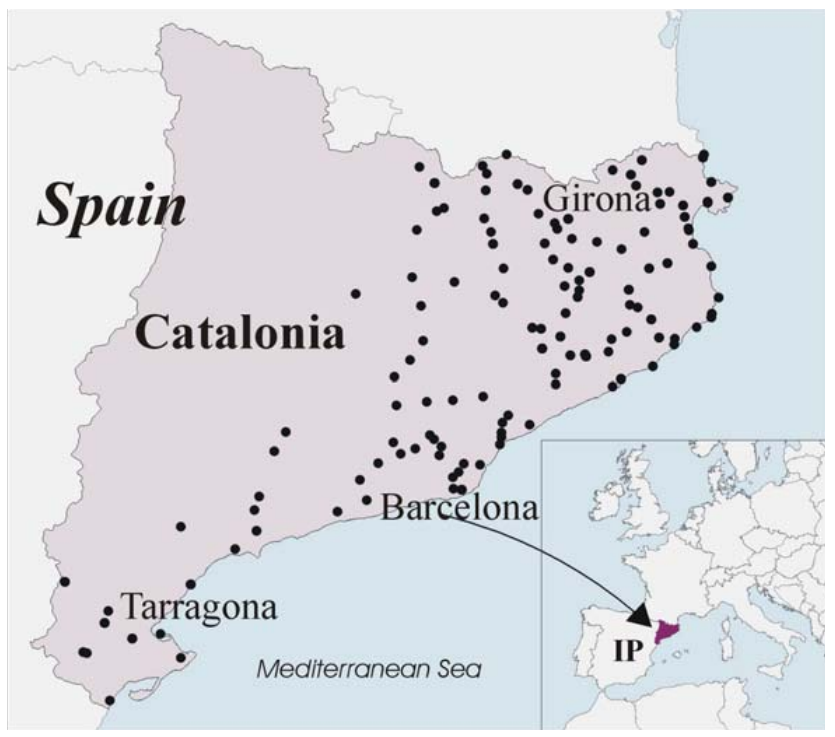

Figure 1. Map of location of the study area and of the points where torrential rainfall has been recorded.

these need to be "homologated" by contrasting their types with those recognized in subjective classifications. Although numerous methods have made use of objective or semiautomated techniques (Huth, 1996), the most currently used ones are those based upon multivariate statistics, such as the Principal Component Analysis and/or Cluster techniques (Esteban et al., 2006), which have been applied in the case of heavy rainfall on Spain's Mediterranean façade (Romero et al., 1999), and upon automatic algorithms, such as the procedures used by Jenkinson and Collison, although the latter has certain limitations in the Mediterranean area (Martin-Vide, 2001).

\section{Data and methodology}

This study compiles the days of rainfall with an amount equal to or greater than $100 \mathrm{~mm}$ in any part of provinces of Barcelona, Girona and Tarragona, in the northeast of the IP (Fig. 1). The $100 \mathrm{~mm}$ in $24 \mathrm{~h}$ has been established as a threshold for identifying heavy rainfall events in Catalonia (Llasat, 2001), which are related to an increase in soil erosion processes (De Luis et al., 2003). To this end, we consulted different sources: the Spanish National Meteorology Institute (INM), the Catalonia Meteorology Service (SMC), the Catalonia Water Agency (ACA) and other networks of observation stations in Catalonia, as well as Barcelona's Royal Academy of Sciences and Arts. The total series analysed are close to 300 , i.e. 2 stations $/ 100 \mathrm{~km}^{2}$. We detected and removed gross errors, and manually checked the spatial consistency of events date. The result is a list of 304 dates on which $100 \mathrm{~mm}$ of rainfall was reached or exceeded during the 1950-2005 period.
The values for atmospheric pressure at sea level were provided by the NCEP-NCAR reanalysis (Kalnay et al., 1996), presenting a resolution of $2.5^{\circ} \times 2.5^{\circ}$ latitude and longitude. The domain selected for the classification of the synoptic patterns is that comprised between parallels $30^{\circ}$ and $70^{\circ} \mathrm{N}$, and between the meridians $30^{\circ} \mathrm{W}$ and $20^{\circ} \mathrm{E}$. Thus, the number of grid points considered totals 357. Although similar articles (Romero et al., 1999) opted for small windows focusing on the IP, in this paper we increased this scope having found that most patterns associated with torrential rainfall in northeast of the IP are linked to synoptic configurations in which the centers of action are located in relatively distant sectors: the Atlantic ocean between $20^{\circ}$ and $30^{\circ} \mathrm{W}$, Central Europe between $10^{\circ}$ and $20^{\circ} \mathrm{E}$, due to the variability of the anticyclone on the central European plain (Martin-Vide and Lopez-Bustins, 2006), and between $50^{\circ}$ and $60^{\circ} \mathrm{N}$, due to the relationship between surface thermal anomalies in the North Atlantic and torrential rainfall episodes in the western Mediterranean (Quereda, 1989). Furthermore, although the influence of upper-levels configuration is decisive in the occurrence of torrential rainfall episodes in the Mediterranean area, the principal ingredient for the development thereof is the input of humid winds, which is detected in the maritime isobar track (Azorín-Molina and Lopez-Bustins, 2004).

For the synoptic classification of the 304 days selected, we applied a Principal Component Analysis (PCA), in TMode (matrix of correlations) (Huth 1996, 2000; LopezBustins et al., 2008; among others). From the matrix of original data, we obtained new variables, Empirical Orthogonal Functions (EOF), which are linear combinations of the original variables. The criterion employed to determine the number of components involved cutting just when a change in the slope on the sedimentation graph was detected (Scree Test), as Huth (1996) states that this is a good method for the classification of synoptic patterns. Although oblique solutions have been recommended in similar articles (Huth, 1996, 2000), in this paper we opted for an orthogonal rotation (Lopez-Bustins et al., 2008), because tests performed with oblique rotations have proved to be less satisfactory (not shown). Specifically, we used the Varimax rotation, which minimized the number of variables with high factorial loadings in each factor, which simplifies the discrimination of the variables assigned to each one of them, that is to say, the dependence among components is reduced (Richman, 1986). Once rotated, each day is classified in the component in which the highest factorial loading is obtained, in absolute values. For a determined number of components retained, twice the amount of classes can be obtained, given that the positive and negative values of the factorial loadings define two opposing types of each component. 
Table 1. Monthly distribution of the number of days with rainfall $\geq 100 \mathrm{~mm}$, according to the 7 selected synoptic patterns.

\begin{tabular}{lcccccccc}
\hline Patterns & +1 & +2 & +3 & +4 & +5 & -1 & -2 & All $^{*}$ \\
\hline January & 2 & 8 & 2 & 2 & 0 & 5 & 0 & 19 \\
February & 4 & 7 & 1 & 0 & 0 & 2 & 0 & 14 \\
March & 3 & 1 & 6 & 1 & 1 & 2 & 1 & 15 \\
April & 1 & 1 & 4 & 2 & 1 & 0 & 3 & 12 \\
May & 2 & 1 & 2 & 6 & 1 & 0 & 0 & 13 \\
June & 10 & 1 & 3 & 2 & 0 & 0 & 2 & 18 \\
July & 3 & 1 & 1 & 4 & 0 & 0 & 1 & 10 \\
August & 10 & 3 & 2 & 1 & 0 & 0 & 1 & 17 \\
September & 26 & 10 & 4 & 3 & 2 & 0 & 0 & 50 \\
October & 16 & 31 & 7 & 3 & 3 & 2 & 0 & 65 \\
November & 9 & 7 & 6 & 1 & 8 & 3 & 1 & 37 \\
December & 6 & 6 & 6 & 2 & 3 & 6 & 4 & 34 \\
\hline Year & 92 & 77 & 44 & 27 & 19 & 20 & 13 & 304 \\
\hline WeMOi* & -0.67 & -1.51 & -1.98 & -0.48 & -2.52 & -2.41 & -0.70 & -1.33 \\
\hline
\end{tabular}

${ }^{*}$ Includes the 12 unclassified days in the 7 patterns finally selected.

** Mean WeMOi values. Data available up to 2000, the period comprising 281 of the 304 days (92.4\%).

\section{Results}

\subsection{Temporal characteristics of days with rainfall equal to or greater than $100 \mathrm{~mm}$ in northeast of the Iberian Peninsula}

Table 1 and Fig. 2 show that October is the month with the highest frequency of days with daily rainfall equal to or greater than $100 \mathrm{~mm}$, a total of 65 days being recorded $(21.4 \%)$. The month with the second largest amount of cases is September, with 50 days (16.4\%), followed by the months of November and December, with 37 (12.2\%) and 34 $(11.2 \%)$ days, respectively. The remaining months present an absolute frequency of below 20 , with a minimum frequency in July, with only 10 cases (3.3\%).

Grouping according to seasons presents a clear maximum in autumn, with exactly half the cases (50.0\%), followed by winter $(22.1 \%)$. Spring and summer show similar percentages (13.1 and $14.8 \%$, respectively). We should highlight the fact that over $20 \%$ of the cases occur in winter, a season that is traditionally considered to present little risk in Catalonia with regard to the occurrence of torrential rainfall, although it is true that the contribution of December plays a decisive role in the relatively high value. The average annual number of days with rainfall greater than or equal to $100 \mathrm{~mm}$ is 5.4 .

\subsection{Synoptic patterns associated with days presenting torrential rainfall in northeast of the Iberian Peninsula}

\subsubsection{Catalogue}

We selected 6 components or EOFs that presented eigenvalues higher than 10, and which account for $87.13 \%$ of total

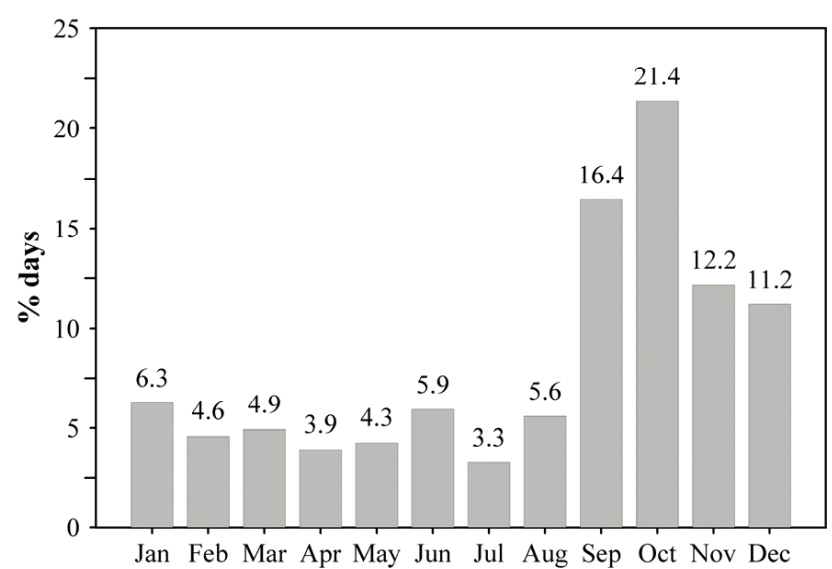

Figure 2. Monthly relative frequencies of the days with daily rainfall equal to or greater than $100 \mathrm{~mm}$ in northeast of the IP.

variance. There are 9 other components with eigenvalues higher than 1 (they account for more variance than the original variables), but these were discarded as they account for a low percentage of total variance and they do not provide any additional information. Likewise, prior to component 7 , the Scree Test shows a jump, which confirms the suitability of retaining the first 6 components. Subsequent rotation redistributes the variance explained among the rotated components.

On retaining 6 components, 12 classes (positive or negative loadings) can potentially be obtained when the 304 days are grouped. Once this grouping has been performed, we found that nine classes group the total of days, although we finally worked with 7 , as two of them only contained 6 days. 


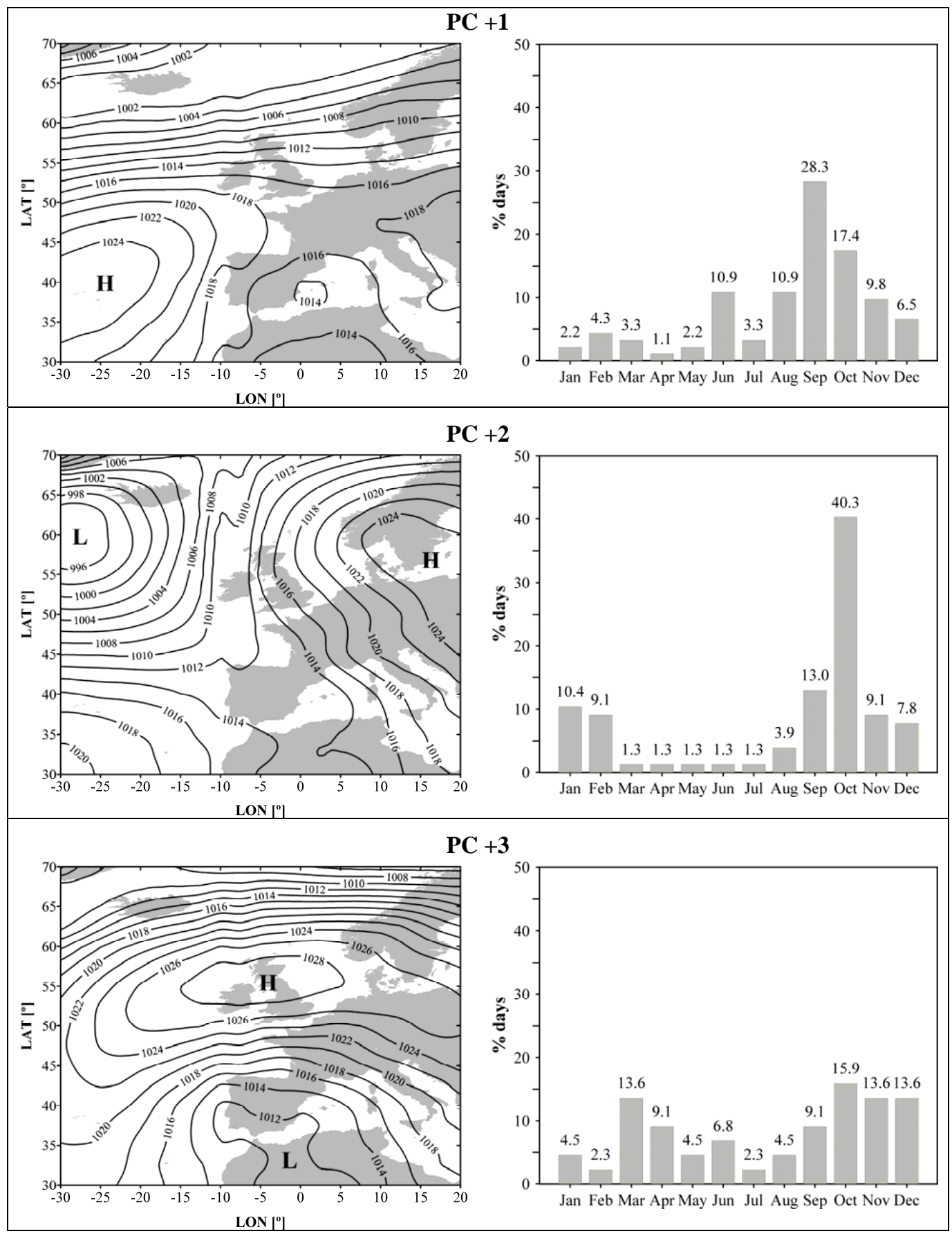

Figure 3. Synoptic patterns (left) and calendars (right) of the situations with torrential rainfall in northeast of the IP.

In order to obtain the average pattern of each of the classes, we calculated the arithmetic mean, cell by cell, of each of the days making up the class considered. For each one of the patterns, we then interpolated the average value of each cell (357) using the kriging method. The final result is shown in Fig. 3.
The seven components selected (Table 1) grouped $96.1 \%$ of the dates with torrential rainfall and define differentiated surface synoptic patterns which are very well characterized in the isobaric sense and in most cases present differentiated intra-annual regimes. Table 2 summarizes the characteristics of the 7 patterns. 


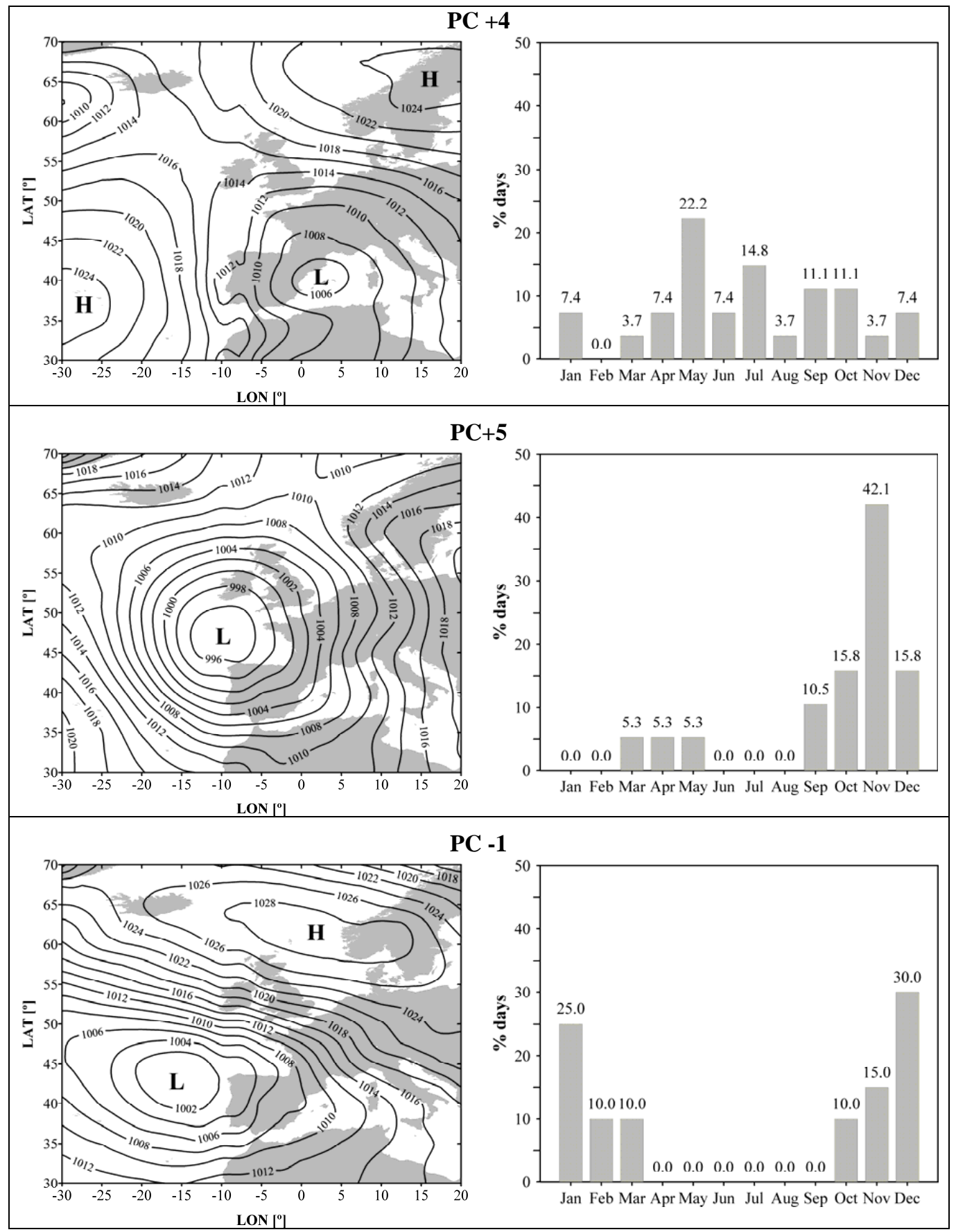

Figure 3. Continued.

The most noteworthy general synoptic features are: 1 ) predominant surface flows from second quadrant in the broad sense, and therefore maritime ones, which is consistent with the great amount of water required by torrential rainfall; and 2) the existence of depressions or low-pressure areas close to or at West/northwest of the IP, or the presence of blocking configurations. Although autumn presents the highest frequency of dates in 4 of the patterns, the calendars can be considered to be significantly varied, with notable difference in the autumn months presenting the maximum.

The patterns called "weak low to the East" and "lowpressure area" clearly reflect the existence of weak gradient surface baric fields in a large number of the dates with torrential rainfall in northeast of Spain. The "continental blocking" pattern is one of the most typical models with a high risk of intense rainfall in Spain's Mediterranean area in autumn, 


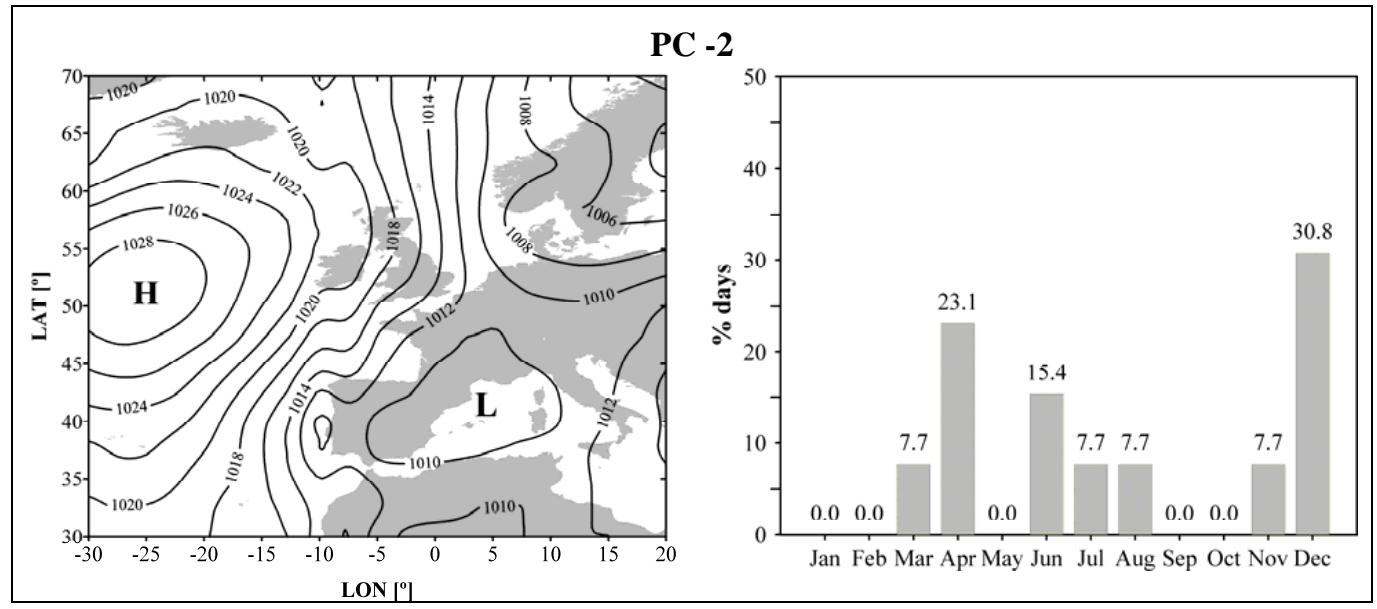

Figure 3. Continued.

Table 2. Synoptic and temporal characteristics of the 7 most frequent patterns producing rainfall equal to or greater than $100 \mathrm{~mm}$ in northeast of the IP.

\begin{tabular}{llllll}
\hline PC & Synthetic denomination & $\begin{array}{l}\text { Air flow over } \\
\text { NE of IP }\end{array}$ & Depression Position & Anticyclone position & Calendar \\
\hline PC+1 & Weak low to the East & E & Balearic Sea & Azores & Maximum in September \\
PC+2 & Continental blocking & SE & N Atlantic & Scandinavia-Central Europe & Notable maximum in October \\
PC+3 & Advection from the East & E & N Africa & British Isles & Equinoctial maxima \\
PC+4 & Centered deep low & Variable & Catalonia & Azores and Scandinavia & Maximum in May \\
PC +5 & Low to the northwest & S & NW IP & - & Notable maximum in November \\
PC-1 & Low to the West & SE & W IP & North Sea & Winter maximum \\
PC-2 & Low-pressure area & - & Western Mediterranean & N Atlantic & Maximum in December \\
\hline
\end{tabular}

which is often associated with isolated depressions at mid or high tropospheric levels (cut-off low, "gota fría" or DANA in Spanish) at IP latitudes (Llasat, 1991). The September, 1962 extreme event has been included in this pattern. Likewise, the "advection from the East" pattern is associated with a situation of diffluent blocking, with a broad calendar of occurrence.

The "centered deep low", albeit not the most represented situation, contains quite a high number of cases. The "low to the northwest" pattern obtained appears to be identical to the situation that led to serious flooding in November, 1982 in the Catalonian Pyrenees, with surface flows between the $\mathrm{S}$ and the SE, and intense circulation from the SW at high levels. Finally, the "low to the West" pattern has certain links to the previous one.

\subsubsection{Synoptic patterns of torrential rainfall and the WeMO index}

The synoptic patterns of the catalogue are representative of the negative phase of the WeMO, a pattern of low-frequency variability (Martin-Vide and Lopez-Bustins, 2006) defined as an alternative to the NAO for explaining the pluviometic behavior on the East coast of the IP. Indeed, the average value of the WeMO index of the dates with rainfall $>100 \mathrm{~mm}$ for the 1950-2000 period is clearly negative, -1.33 (Table 1). The number of days with torrential rainfall with a positive index is less than $15 \%$ and just less than $5 \%$ occurred with an index higher than +1 . It can be said that in a day with a WeMO index higher than +2 it is practically impossible to exceed $100 \mathrm{~mm}$ in $24 \mathrm{~h}$ in coastland of Catalonia. Finally, the average values of the WeMO index of the dates with torrential rainfall classified in each of the 7 patterns are negative (Table 1). Indeed, the Western Mediterranean Oscillation Index (WeMOi), which correlates satisfactorily with rainfall on the East coast of the IP, reaches its absolute minimum in October (Martin-Vide and Lopez-Bustins, 2006).

\section{Conclusions and future work}

The database created, showing the days of rainfall equal to or greater than $100 \mathrm{~mm}$ in provinces of Barcelona, Girona and Tarragona (coastland area of Catalonia), comprises 304 dates in the 1950-2005 period. Over $60 \%$ of the dates belong to 
the final four-month period of the year, which confirms the preference of torrential rainfall in the region for autumn and for the month of December.

Using a Principal Component Analysis of surface pressure, extracted from the NCEP-NCAR reanalysis, of the aforementioned 304 dates for the grid made up of the 357 points of the $30^{\circ} \mathrm{N}-70^{\circ} \mathrm{N}$ and $30^{\circ} \mathrm{W}-20^{\circ} \mathrm{E}$ domain, we constructed a catalogue of synoptic patterns with 7 types, which highlights the variety of synoptic situations producing torrential rainfall in northeast of the IP.

The most noteworthy synoptic characteristics of the 7 patterns (Table 3) are the predominance of surface flows of the second quadrant, maritime ones, and the existence of depressions or low-pressure areas close to or at West/northwest of the IP, or the presence of blocking configurations. Moreover, there is a notable predominance of negative WeMOi values in all the patterns and on all the dates considered.

In the future, the torrential rainfall database will be further improved and an attempt will be made to homogenize the resulting time series. The latter will enable us to test an analysis of the tendencies of the frequency of intense rainfall, a theme of particular interest in the context of current anthropic climate change. Other aspects to be developed in the future are: study of the spatial distribution of torrential rainfall associated with the different synoptic patterns detected; consideration of other levels, aside from surface level, in the classification proposal; and synoptic analysis of the whole Mediterranean façade of the IP.

Acknowledgements. We wish to thank the NCEP-NCAR reanalysis project, for providing the surface pressure data. The data for the 1959-2005 period were provided by the Climatic Research Unit (CRU), whereas those for the previous years were the courtesy of Ian Harris. Our thanks to the Spanish National Meteorology Institute, Catalonia Meteorology Service, Catalonia Water Agency and to the Barcelona's Royal Academy of Sciences and Arts for the pluviometry data. This research project is framed within the RIMARC network (CGL2004-21663-E), the IPIBEX project (CGL2005-07664-C02-01), the COST-733 Action, of the Institut de l'Aigua (UB) and in the Acción Integrada (Integrated Action) CGL2004-21441-E of the Spanish Committee of the WCRP, to which the first co-author belongs.

Edited by: F. Stel and D. B. Giaiotti

Reviewed by: two anonymous referees

\section{References}

Azorín-Molina, C. and López-Bustins, J. A.: Catálogo sinóptico manual y causas atmosféricas de la precipitación en la provincia de Alicante, Boletín de la AGE, 38, 279-310, 2004.

De Luis, M., González-Hidalgo, J. C., and Raventós, J.: Effects of fire and torrential rainfall on erosion in a Mediterranean gorse community, Land Degrad. Dev., 14, 203-213, 2003.

Esteban, P., Martin-Vide, J., and Mases, M.: Daily atmospheric circulation catalogue for western Europe using multivariate techniques, Int. J. Climatol., 26, 1501-1515, 2006.
Huth, R.: An intercomparison of computer-assisted circulation classification methods, Int. J. Climatol., 16, 893-992, 1996.

Huth, R.: A circulation classification scheme applicable in GCM studies, Theor. Appl. Climatol., 67, 1-18, 2000.

Kalnay, E., Kanamitsu, M., Kistler, R., Collins, W., Deaven, D., Gandin, L., Iredell, M., Saha, S., White, G., Woollen, J., Zhu, Y., Chelliah, M., Ebisuzaki, W., Higgins, W., Janowiak, J., Mo, K. C., Ropelewski, C., Wang, J., Leetma, A., Reynolds, R., Jeene, R., and Joseph, D.: NCEP/NCAR 40-year reanalysis project, B. Am. Meteorol. Soc., 77, 437-471, 1996.

Llasat, M. C.: Gota fría, Marcombo, Barcelona, 165 pp., 1991.

Llasat, M. C.: An objective classification of rainfall events on the basis of their convective features: application to rainfall intensity in the northeast of Spain, Int. J. Climatol., 21, 1385-1400, 2001.

Llasat, M. C. and Rodríguez, R.: Extreme rainfall events in Catalonia: the case of 12 November 1988, Nat. Hazards, 5, 133-151, 1992.

Lopez-Bustins, J. A., Martin-Vide, J., and Sanchez-Lorenzo, A.: "Iberia winter rainfall trends based upon changes in teleconnection and circulation patterns, Global Planet. Change, doi:10.1016/j.gloplacha.2007.09.002, 2008.

Martín Vide, J.: Geographical Factors in the Pluviometry of Mediterranean Spain: Drought and Torrential Rainfall, in: U.S.Spain Workshop on Natural Hazards, 9-25, The University of Iowa, Iowa Institute of Hydraulic Research, 1994.

Martin-Vide, J.: Limitations of an objective weather-typing system for the Iberian Peninsula, Weather, 56, 7, 248-250, 2001.

Martín Vide, J.: Valores pluviométricos extremos en la fachada mediterránea española, in: Chastagnaret y Gil Olcina, Riesgo de inundaciones en el Mediterráneo occidental, Madrid, Casa de Velázquez y Universidad de Alicante, 2006.

Martín Vide, J. and Llasat, M. C.: Las precipitaciones torrenciales en Cataluña, Serie Geográfica, 9, 17-26, 2000.

Martin-Vide, J. and Lopez-Bustins, J. A.: The Western Mediterranean Oscillation and rainfall in the Iberian Peninsula, Int. J. Climatol., 26, 1455-1475, 2006.

Quereda, J.: La ciclogénesis y las gotas frías del Mediterráneo Occidental, Diputació de Castelló, 135 pp., 1989.

Ramis, C., Llasat, M. C., Genovés, A., and Jansà, A.: The October87 Floods in Catalonia. Synoptic and Mesoscale Mechanisms, Meteorol. Appl., 1, 337-350, 1994.

Ramis, C., Arús, J., López, L., and Mestre, A.: Two cases of severe weather in Catalonia (Spain). An observational study, Meteorol. Appl., 4, 207-217, 1997.

Richman, M. B.: Rotation of principal components, J. Climatol., 6, 293-335, 1986.

Romero, R., Sumner, G., Ramis, C., and Genovés, A.: A classification of the atmospheric circulation patterns producing significant daily rainfall in the Spanish Mediterranean area, Int. J. Climatol., 19, 765-785, 1999.

Tomás Quevedo, A.: Causas meteorológicas de las inundaciones del bajo Vallés, Llano de Llobregat y el Maresme, Estudios Geográficos, 91, 137-146, 1963.

Wheeler, D. and Martín Vide, J.: Las precipitaciones torrenciales del 1 al 5 de octubre de 1987 en Barcelona, Riegos y Drenajes XXI, 22, 61-67, 1988. 